\title{
GIS Based Inventorization of Fishes in River Ganga
}

\author{
Basanta Kumar Das*, Manisha Bhor, Archisman Ray, Supriti Bayen, Nitish Kumar Tiwari, Shreya Roy, Subhadeep \\ Das Gupta, Himanshu S Swain, Canciyal Johnson and Raju Baitha
}

ICAR-Central Inland Fisheries Research Institute, India

Submission: November 15, 2021; Published: December 10, 2021

*Corresponding author: Basanta Kumar Das, ICAR-Central Inland Fisheries Research Institute, Barrackpore, Kolkata-700120, India

\section{Abstract}

Geographic information system is being applied to various studies to efficiently manage information and project it for decision making and planning purposes. One such application of GIS has been in inland fisheries to inventorize availability and distribution of fish species in river Ganga at selected sampling stations. The stations were distributed in four stretches along the entire course of river Ganga from source to sea. Fish samples were not only taken from the main channel but also from adjacent landing centres. Data collected was organised and analysed in the GIS environment using ARC-GIS 9.3. The study was steered towards observing the species distribution in years 2017 and 2020 and changes that took place during that time span. Among other stations, Bijnor recorded the highest number of species while Harsil recorded the lowest number of species.

Keywords: River Ganga; GIS based data inventory; Fish availability; Abundance

\section{Introduction}

Geographic information system (GIS) can be recommended for designing of spatial survey through analysis of spatial data [1]. The application of GIS has been used for many different tasks in fishery biology that involve a spatial dimension, including mapping fish habitats and analyzing spatial and temporal changes in fish distributions, determining the effects of land use on fish populations [2-4]. A GIS can be used to assist with the design of surveys and provide a rational basis for the selection of sites from a river network [5]. Fish species and assemblage relationships with habitat have been studied using two primary approaches that relies on small-scale studies of microhabitat use or habitat partitioning and large-scale studies to test for assemblage patterns that are correlated with environmental variables [6]. Understanding the species - and assemblage-habitat relationships of large river fishes has been historically limited by the large size and spatial complexity of river ecosystems.

However, a GIS constructed with remotely sensed physical data that are spatially explicit for individual occurrences of organisms by species should provide ecologists with appropriate tools to detect habitat use patterns for species and assemblages in these ecosystems [4].

In India, the Ganga is revered as Mother Ganga and has been the source of life for thousands of years, being mentioned in oldest scriptures $[7,8]$. Impact of manifold increase in human population along the bank of a river is adversely affecting the river waters through discharge of toxic contamination in most of the rivers and there is no exception for river Ganga. In fact, river Ganga passes through three very densely populated states, namely, Uttar Pradesh with 829 persons per sq. kms [9], Bihar with 1106 persons per sq. kms [9] and West Bengal 1028 persons per sq. kms [9]. This strong anthropogenic influence inflicted a sharp deterioration of water quality with increased levels of harmful elements in river water beyond permissible limits [1013]. Hence, the obvious impact was also observed in the habitat of native fish species found in the riverine ecosystem. The alteration of habitat, illegal fishing, pollution, introduction of invasive fish species has become threatening to fish diversity as 29 fish species were recorded under threatened category in Ganga river [14]. In an effort to organise the fish species availability and distribution on GIS platform, an attempt was made to create an inventory of fish species in Ganga river system. This would not only account for the species available but would also be a repository from where data can be retrieved whenever required for further analysis, for example to calculate species abundance at a particular stretch. The study narrows down the broad and vast aspects of the river to focus upon the richness of fish species aggregating and distributed over the entire stretch of river Ganga. Analytical studies carried 
out through remote sensing and GIS can give a structural support to decision makers and planners to assess the urban and rural impact upon sustainable management of aquatic biodiversity in river system of Ganga.

\section{Materials and Methods}

\section{Study area}

Ganga River is the most important source of water flowing through the northern to the eastern parts of the country stretching across $77^{\circ} 58^{\prime} 47.44^{\prime \prime}$ E longitude to $88^{\circ} 30^{\prime} 37.89^{\prime \prime} \mathrm{E}$ longitude and $22^{\circ} 18^{\prime} 6.43^{\prime \prime} \mathrm{N}$ latitude to $31^{\circ} 2^{\prime} 49.31^{\prime \prime} \mathrm{N}$ latitude. The present study was conducted at Nineteen sampling stations namely Harsil, Tehri, Haridwar, Bijnor, Narora, Farrukhabad, Kanpur, Prayagraj, Varanasi, Buxar, Patna, Bhagalpur, Farakka, Berhampore, Balagarh, Tribeni, Godakhali, Diamond Harbour and Fraserganj covering Uttarakhand, Uttar Pradesh, Bihar and West Bengal for data inventorization of fish availability as well as distribution (Figure 1).

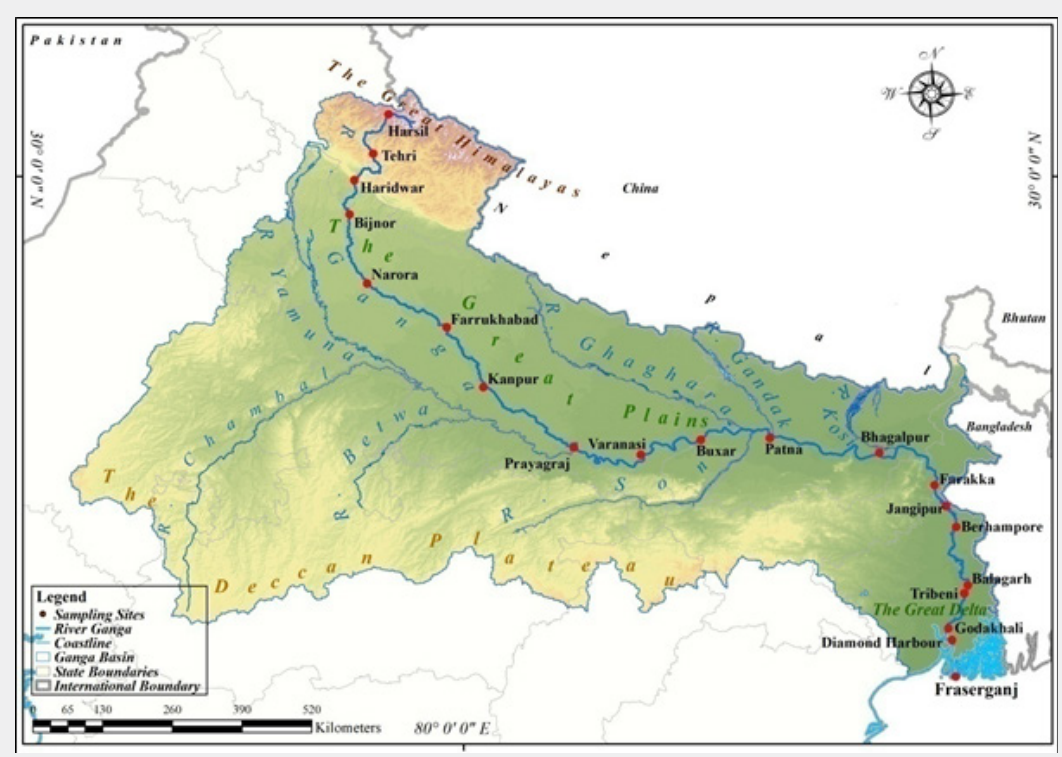

Figure 1: Map showing course of river Ganga along with the sampling stations.

The sampling stations were divided into 4 divisions. The study area is focused upon the stations observing the diversity of fish species as well as the accessibility at each sampling station along the river course. Stretch 1 spreads from Harsil to Bijnor and is known as the upper stretch, Stretch 2 spreads from Bijnor to Varanasi and is known as the Middle stretch Stretch 3 spreads from Buxar to Nabadwip and is known as the Lower stretch and Stretch 4 spreads from Nabadwip to Fraserganj and is known as the Estuarine stretch.

\section{Collection and identification of fish sample}

The fish samples were collected from the main river channel as well as adjacent landing centres. Various selective and nonselective gears like gill nets, seine nets, set barrier and falling nets, cast nets, drag nets, bag nets, traps etc. were selected for the fish catch from the selected sampling station during this period. The fish specimens were identified using the taxonomic characteristics as per [15-18].

\section{Data analysis through GIS}

Line format of vector data has been generated to demarcate the main channel of river Ganga. These have been used for mapping twenty sampling locations in the form of point vectors.
Each point represents an individual sampling station having all species information attached as attributes to the same table. The total number of fish species found along the river at all the stations taken together aggregated up to 190. Each species was distributed uniquely throughout this stretch and their distributions were represented in separate layers. This resulted in the creation of 190 layers as individual species distribution for each species. They were then used along with other layers to compute thematic layers and subsequently compose maps using ARC-GIS 9.3 software.

\section{Results}

The present study revealed that a total of 190 fish species were recorded along Ganga River stretch. The highest number of fish species was found at Bijnor (107 species) close to foothills of the Himalayas, followed by Narora which recorded the second highest number of fish species (95 species) and Farakka at the third highest position recorded (86 species) (Table 1 and Figure 2). Only two species have been recorded from Harsil in 2020 accounting for the lowest number of species recorded. A detailed species composition for Bijnor has been depicted in a map in (Figure 4). 


\section{International Journal of Environmental Sciences \& Natural Resources}

Table 1: The changing pattern of fish species distribution during 2017-2020.

\begin{tabular}{|c|c|c|c|}
\hline Stations & No. of Species (2017) & No. of Species (2020) & Change in No. of Species (2017 to 2020) \\
\hline Harsil & 1 & 2 & 1 \\
\hline Tehri & 3 & 8 & 38 \\
\hline Haridwar & 10 & 107 & 27 \\
\hline Bijnor & 69 & 95 & 46 \\
\hline Narora & 68 & 83 & 35 \\
\hline Farukhabad & 37 & 83 & 18 \\
\hline Kanpur & 48 & 85 & 20 \\
\hline Prayagraj & 67 & 83 & 14 \\
\hline Varanasi & 63 & 79 & 8 \\
\hline Buxar & 58 & 67 & 9 \\
\hline Patna & 53 & 68 & 19 \\
\hline Bhagalpur & 60 & 86 & 5 \\
\hline Farakka & 77 & 76 & 18 \\
\hline Berhampore & 57 & 67 & 12 \\
\hline Balagarh & 62 & 62 & 4 \\
\hline Tribeni & 44 & 33 & 4 \\
\hline Godakhali & 21 & 38 & \\
\hline Diamond Harbour & 34 & 66 & \\
\hline Fraserganj & 62 & & \\
\hline
\end{tabular}

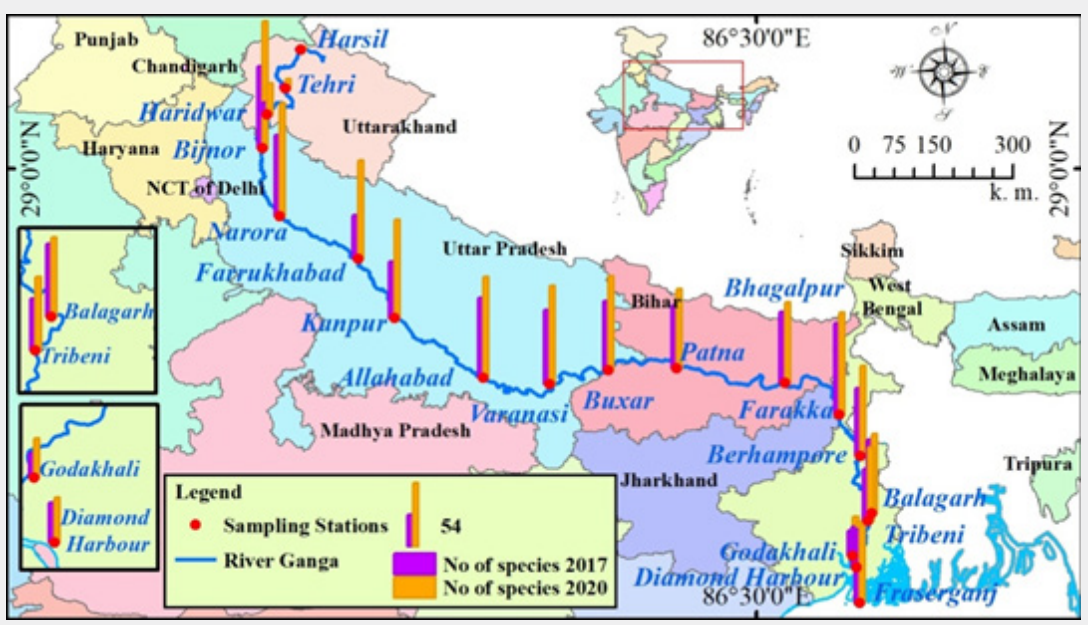

Figure 2: GIS Map showing distribution of number of species found during 2017-2020.

A change in the number of species from 2017 and 2020 has also been observed in this study. An encouraging fact has been observed as an increase in the number of fish species for all of the sampling stations (Figure 3). The highest observed being for Farukhabad and the lowest for that of Harsil. The observation also shows an average increase of more than $50 \%$ in the number of fishes species considering all the sampling stations from the source to the sea. Farukhabad has shown the highest amount of increase with a difference of 46 species between 2020 and 2017.
This was followed by Bijnor and Kanpur both having a difference of more than 30 species between 2020 and 2017. Narora, Buxar and Varanasi have recorded a difference of 20 and more than 20 species each between the same time span. Berhampore, Tribeni, Prayagraj, Haridwar, Patna and Godakhali all have recorded an increase of more than 10 species from 2017 to 2020. Rest of the stations, namely, Farakka, Bhagalpur, Tehri, Balagarh, Diamond Harbour, Fraserganj and Harsil have a difference of less than 10 species increase between 2017 and 2020 (Figure 4). 


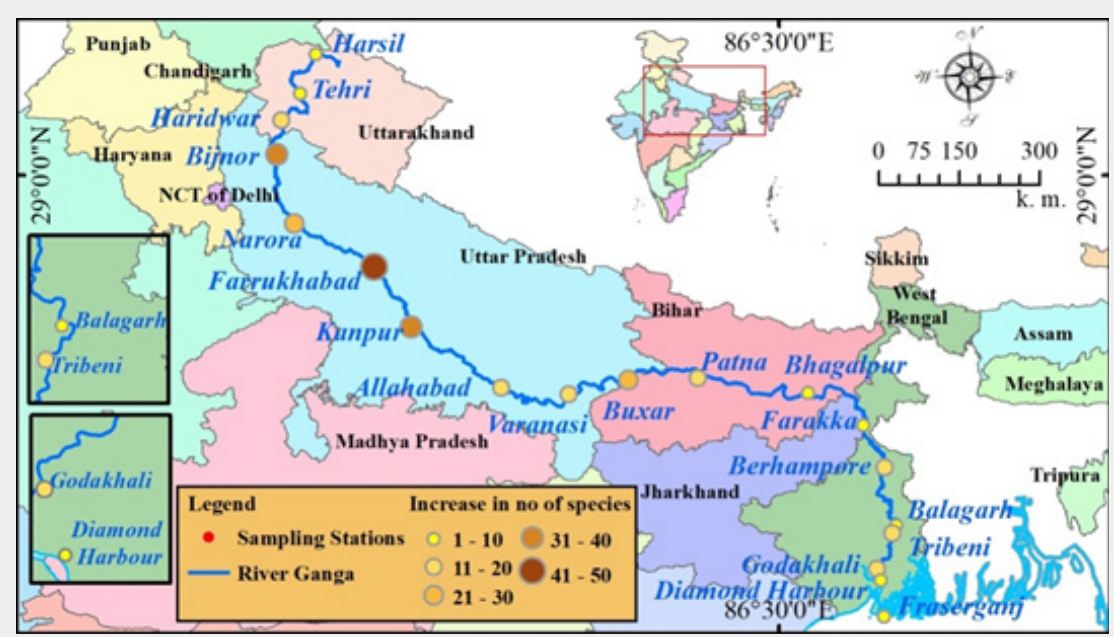

Figure 3: GIS Map showing increase in number of species found in each sampling station during $2017-2020$.

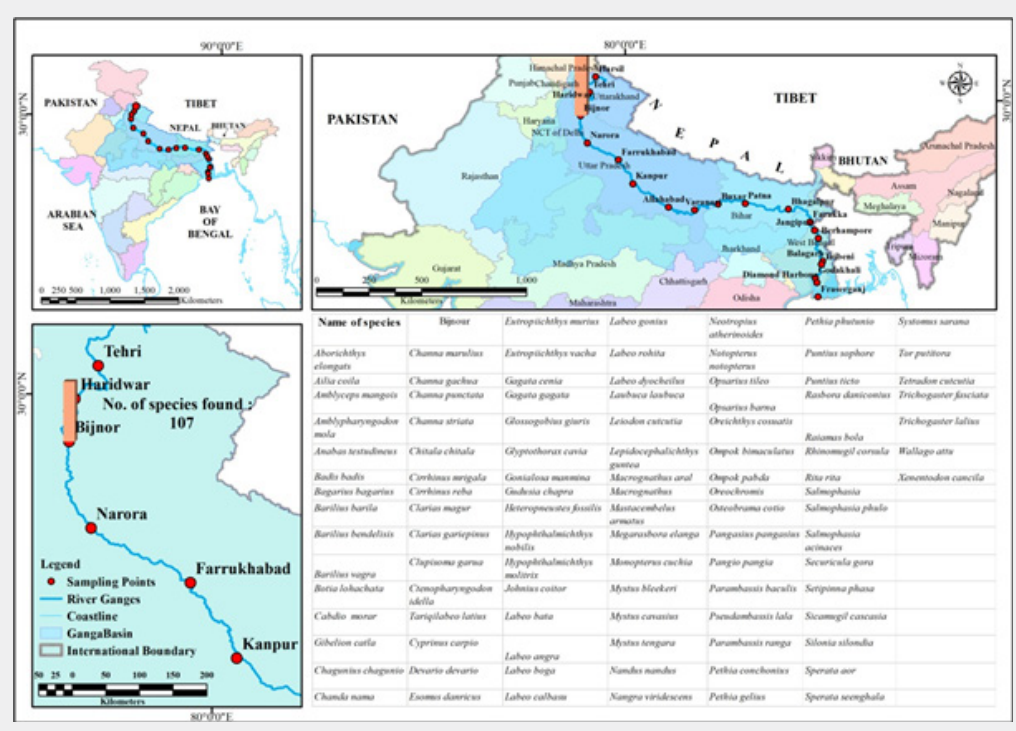

Figure 4: Location of sampling stations with their species composition.

\section{Discussion}

The use of GIS in ecological studies allowed identification of the habitat resolution as well as perform as a repository system for fish distribution along Ganga River stretch. The associated fish distribution and assemblages are predicted to change with this physical variation $[19,20]$, but details for long stream reaches or entire streams are still unknown. The fish distribution and habitat specific classification were reported based on GIS framework and the habitat was found greatest for fish species richness with quality of entire stream as well as suitable water quality [21]. Temporal variation in physical attributes of streams [22] is expected with flow events including floods, droughts, or anthropogenic alterations (dams, dewatering, etc.) [23-25] and associated fish distribution and assemblages are predicted to change [26]. It may be assumed from [24] and the current analysis, that with every occasion of fresh supply of water brought by tributaries, moribund condition within the river water has been rejuvenated to support increased number of species. Highly populated areas with point and non-point sources of contamination do diversely affect species richness in a river system [27]. Fish species may decrease or increase in abundance based on their traits [28], but detailed studies of fish assemblage responses to temporal variation in physical stream habitat only exist for small streams and short reaches [29].

The presence of a very high number of fish species in Bijnor cause presence of less pollutant at upper stretch of Ganga as the river water was found suitable for drinking after disinfection, irrigation and other household purposes [30] may be indicative of the large volume of mineral rich fresh water brought down from upper reaches by river channels at the foot hills which act as an influencing ecological factor for fish species richness and their distribution [31]. At Narora, contamination of river water has not 
yet set in to adversely affect the richness of species found at the particular station. Harsil and Tehri have a highly elevated location and lesser volume of water that negates the favourable conditions for a higher number of species to be found there. The rise in species richness at Haridwar, may be attributed to the confluence of rivers Alakananda and Mandakini, which enrich the ecosystem as well as enhance fish diversity [32]. At middle stretch of Ganga River, from Farukhabad up to Farrakka Barrage, variation was observed in fish species diversity among different stations. There was a significant increase in number of fish species. indicating improvement of aquatic habitat. The responsible factors for alteration of fish habitat may be hydrological diversion, dam construction, pollution, siltation, overfishing and introduction of exotic fish species [14]. In stark contrast to this within a distance of approximately $127.26 \mathrm{kms}$ south east of Farrakka Barrage at Berhampore there is a sudden drop in species to 76 which may be attributed to the construction of Farakka barrage affecting the natural riverine environment for many fish species along with estuarine fishery as well as associated factors [33]. However, the fish species diversity was recorded quite low at Balagarh (67) and Tribeni (62). The major reason may be pollution arising from thermal effluent from Tribeni Thermal power plant and also industrial effluent from adjacent industrial areas.

As the river passes from Tribeni through the metropolitan city of Kolkata, it reaches Godakhali only about $30 \mathrm{kms}$ south - east of the city. The stations of lower estuary like Godakhali, Diamond Harbour and Fraserganj receive tidal waters from the estuary that enrich the ecosystem. Hence, the environment became favourable for fish species assemblage. Higher number of fishes were recorded from lower estuary of river Ganga as the estuarine zone establish the connection between freshwater and adjacent marine areas, providing passages for migratory fish species for different biological activities [34]. Though, the usages of destructive fishing gear had obvious effect on fish juvenile catches [35] thereby, leading to rapid declination of fish stock in estuarine ecosystem.

Additional applications of GIS were also reported earlier to examine habitat use (niche breadth) and availability of suitable habitat for stream fishes [36] found high variation in seasonal niche breadth and available habitats using a GIS for a stream fish assemblage. In the present study, the overall changes in fish diversity were observed in increasing trend through the stretch of river Ganga. To visualize the changing pattern of fish structure on a GIS platform makes it simpler for understanding. The increasing trend of fish assemblage structure indicates the improving water quality of riverine health condition. Large riverine systems are most significant resource for human. Community specific fishbased index has been developed earlier for assessing as well as monitoring the large riverine ecology $[37,38]$ as fish was identified one of the suitable biological indicators for evaluating condition of aquatic health [39].

\section{Conclusion}

The GIS database can behave as a repository of all data that can be mined for every customized need of clients. Representations in tabular format is vastly different from those of graphical format with the later giving a clear understanding of not only the figurative values but also an easy procedure to understand impression of associated information. In an attempt to represent distribution of richness of fish species, GIS can enable the creation and maintenance of a data repository in the form of a database. Appropriate maps generated in accordance with definite client requirements can simplify understanding of complex interactions of natural phenomenon graphically represented through ARCGIS. Fish species richness at sampling stations has found a technologically advanced method of representation by GIS. With progress of research and advanced specialized needs of humanity, this could be adapted to develop more sophisticated fishery information system.

\section{Acknowledgement}

Authors are grateful to National Mission for Clean Ganga (NMCG), Ministry of Jal Shakti, Govt. of India, New Delhi for financial support.

\section{References}

1. Burrough PA (2001) GIS and geostatistics: Essential partners for spatial analysis. Environ Ecol Stat 8: 361-377.

2. Isaak DJ, Hubert WA (1997) Integrating New Technologies into Fisheries Science: The Application of Geographic Information Systems. Fisheries 22(1): 6-10.

3. Kapetsky JM (2001) Recent applications of GIS in inland fisheries. In: Nishida T, Hollingworth CE, Kailola PJ (Eds.), Proceedings of the First International Symposium on GIS in Fishery Science. Fishery/Aquatic GIS Research Group, Kawagoe-City, Japan

4. Fisher W, Rahel F (2004) Geographic Information Systems in Fisheries. - American Fisheries Society. Massachusetts, p. 276.

5. Toepfer CS, Fisher WL, Warde WD (2000) A Multistage Approach to Estimate Fish Abundance in Streams Using Geographic Information Systems. North Am J Fish Manag 20(3): 634-645.

6. Jackson DA, Peres-Neto PR, Olden JD (2001) What controls who is where in freshwater fish communities - The roles of biotic, abiotic, and spatial factors. Can J Fish Aquat Sci 58(1): 157-170.

7. Parua PK (2009) The Ganges. Water Science and Technology Library.

8. Census (2011) Primary Census Abstracts, Registrar General of India, Ministry of Home Affairs, Government of India.

9. Chandra PK (2018) Cultural Significance and Current Conservation Practices of the Ganga's Ecosystem and Environment. Applied Ecol and Environ Sciences 6(4): 128-136.

10. Bilgrami KS, Kumar S (1998) Bacterial contamination in water of the River Ganga and its risk to human health. International Journal of Environmental Health Research 8(1): 5-13.

11. Basu S, Down TE (2014) Ganga pollution: Uttar Pradesh issues notices to. 1-6.

12. Kumar V, Bharti PK, Talwar M, Tyagi AK, Kumar P (2017) Studies on high iron content in water resources of Moradabad district (UP), India. Water Science 31(1): 44-51.

13. Dwivedi S, Mishra S, Tripathi RD (2018) Ganga water pollution: A potential health threat to inhabitants of Ganga basin. Environment International. 117: 327-338. 
14. Sarkar UK, Pathak AK, Sinha RK, Sivakumar K, Pandian AK, et al. (2012) Freshwater fish biodiversity in the River Ganga (India): Changing pattern, threats and conservation perspectives. Reviews in Fish Biology and Fisheries 22(1): 251-272.

15. Day F (1888) The fishes of India: being a natural history of the fishes known to inhabit the seas and fresh waters of India, Burma, and Ceylon.

16. Talwar PK, Jhingran AG (1991) Inland fishes of India and adjacent countries. Vol. I \& II, Oxford and IBH Publishing Co. Pvt. Ltd. New Delhi, India.

17. Jayaram KC (1999) The freshwater fishes of the Indian Region. Narendra Publishing House, Delhi, 551.

18. Nelson JS (2006) Fishes of the world 4, Wiley New York.

19. Schaefer JF, Kerfoot JR (2004) Fish assemblage dynamics in an adventitious stream: a landscape perspective. Am Mid Nat 151(1): 134-145.

20. Hitt NP, Angermeier PL (2008) River-stream connectivity affects fish bioassessment performance. Environ Manage 42: 132-150.

21. Meixler MS, Bain MB (2012) A GIS framework for fish habitat prediction at the river basin scale. Int J Ecol 2012.

22. Borneman E (2014) How Rivers Change the Landscape. Geogr Realm, pp. 1-12.

23. Nelson SA (2016) River Systems \& Causes of Flooding.

24. Rytwinski T, Taylor JJ, Bennett JR, Smokorowski KE, Cooke SJ (2017) What are the impacts of flow regime changes on fish productivity in temperate regions? A systematic map protocol. Environ Evid 6(13).

25. Yoshida Y, Lee HS, Trung BH, Tran HD, Lall MK, et al. (2020) Impacts of mainstream hydropower dams on fisheries and agriculture in lower mekong basin. Sustainability (Switzerland) 12(6): 1-21.

26. Gorski K, Buijse AD, Winter HV, Leeuw JD (2012) Geomorphology and flooding shape fish distribution in a large-scale temperate floodplain. River research and Applications, pp. 1226-1236.

27. Ibarra AA, Dauba F, Lim P (2005) Influence of non-point source pollution on riverine fish assemblages in south west France. Ecotoxicology 14(5): 573-588.

28. Frimpong EA, Angermeier PL (2010) Trait-based approaches in the analysis of stream fish communities. Am Fish Soc Symp 73: 109-136.

29. Grossman GD, Ratajczak RE (1998) Long-term patterns of microhabitat use by fish in a southern Appalachian stream from 1983 to 1992: Effects of hydrologie period, season and fish length. Ecol Freshw Fish $7(3): 108-131$.

30. Haritash AK, Gaur S, Garg S (2016) Assessment of water quality and suitability analysis of River Ganga in Rishikesh, India. Appl Water Sci 6: 383-392.

31. Malik DS, Sharma MK, Sharma Arvind Kumar, Sharma, Amit Kumar (2021) Status of fish diversity and their Habitat Ecology in the upper Ganga Basin, Uttarakhand 27.

32. Sharma P (2015) Diversity and composition of fresh water fishes of river Ganga Devprayag to Haridwar. Int J Educ Sci Res Rev 8-14.

33. Mitra S, Ghosh S, Satpathy KK, Bhattacharya BD, Sarkar SK, et al. (2018) Water quality assessment of the ecologically stressed Hooghly River Estuary, India: A multivariate approach. Marine Pollution Bulletin 126: 592-599.

34. Roshith CM, Sharma AP, Manna RK, Satpathy BB, Bhaumik U (2013) Ichthyofaunal diversity, assemblage structure and seasonal dynamics in the freshwater tidal stretch of Hooghly estuary along the Gangetic delta. Aquat Ecosyst Heal Manag 16(4): 445-453.

35. Remesan MP, Pravin P, Meenakumari B (2009) Non-selective fishing gears and sustainability issues in the Hooghly-Matlah estuary in West Bengal, India. Asian Fish Sci 22: 297-308.

36. Knouft JH, Caruso NM, Dupre PJ, Anderson KR, Trumbo DR, et al. (2011) Using fine-scale GIS data to assess the relationship between intra-annual environmental niche variability and population density in a local stream fish assemblage. Methods Ecol Evol 2(3): 303-311.

37. Jia YT, Chen YF (2013) River health assessment in a large river: Bioindicators of fish population. Ecol Indic 26: 24-32.

38. Kanno Y, Vokoun JC, Beauchene M (2010) Development of dual fish multi-metric indices of biological condition for streams with characteristic thermal gradients and low species richness. Ecol Indic 10(3): 565-571.

39. Karr JR, Fausch KD, Angermeier PL, Yant PR, Schlosser IJ (1986) Assessing biological integrity in running waters. Illinois Nat Hist Surv Spec Publ 5: 1-28.

\section{Your next submission with Juniper Publishers} will reach you the below assets

- Quality Editorial service

- Swift Peer Review

- Reprints availability

- E-prints Service

- Manuscript Podcast for convenient understanding

- Global attainment for your research

- Manuscript accessibility in different formats

( Pdf, E-pub, Full Text, Audio)

- Unceasing customer service

Track the below URL for one-step submission https://juniperpublishers.com/online-submission.php 